\title{
Condition of Branches and Subsections as well as Charitable Enterprises of the Aisyiyah Autonomous Organization in Sukabumi Regency
}

\author{
Prahasti Suyaman, Leonita Siwiyanti, Yuni Sri Wahyuni
}

Universitas Muhammadiyah Sukabumi

\begin{abstract}
Aisyiyah as autonomous organization plays a significant role in building the quality of Islamic women. The 'Aisyiyah movement, similar to Muhammadiyah, is defined as a movement in preaching which has an effort of forming QoryahThoyyibah. The establishment of muslimah being highly empowered by 'Aisyiyahwas commenced from reforming internally by which it was conducted a mapping of condition of manpower and organization, namely in this research the 'Aisyiyah organization located in Sukabumi region. The research was aimed at arranging accurate data and basics in creating plans of preach, consisting in the preparing the manpower, preach method, and its facilities.

The method applied in the research was survey that focused on the condition of branch and subsection of 'Aisyiyah, in terms of a mapping of the organization's manpower and a mapping of condition of branch, subsection, as well as charitable enterprises of 'Aisyiyah distributed in Sukabumi Regency.

The research concludes that the amount of Branches and Subsection of 'Aisyiyah in Sukabumi Regency is encompassed into the category of active, yet it still requires supervision in the hope that it can increase well and in a larger number.
\end{abstract}

Keywords: 'Aisyiah, Sukabumi Regency, Branch, Subsection

\section{INTRODUCTION}

The history of 'Aisyiyah is Sukabumi was generated after the establishment of Muhammadiyah in Sukabumi. In the record of ANRI (2012), 'Aisyiyah was yet to be an autonomous organization in Sukabumi in 1959-it was a part of Muhammadiyah's board of management in charge of women, along with Nasyiatul 'Aisyiyah. The movements considered to be significant today are branches and subsections. These branches and subsections are the important elements in operating the wheel of movement of the organization as well as in the operation of preach, which get along directly with society.

Regarding the problem identified in these branches and subsections, it will be elucidated from its quantity and its degree of distribution, consisting in: First, the amounts of subsections which are not significant compared to the amounts of villages/sub-districts in the country. Secondly, the condition of static or inactive subsections. Third, mosques in the area of Muhammadiyah which are not well managed. Fourth, Movement of Jamaah and Preaching of Jamaah which have not been implemented since being programmed in 1968.Fifth, activities of Muhammadiyah in the area of weak basis.Lastly, activation of other organizations or groups that run expansion on movement, either from Islamic or other religious backgrounds. Either vacuum, static, or inactive, as well as not all Districs and Subdistrics/Villages have not been organizationally nudged by Muhammadiyah, are actually not weak by means of concept, but it's more to the matter of implementation and supervision. Given that the concepts of organizations of Branches and Subsections have been long established, such as the empowerment of mosques, charitable enterprises, micro economy, and even the Movements of Jamaah and Preach which have been programmed since 1968, the implementation and supervision are yet to run optimally. Therefore, in the actual field, Branches and Subsections are in trouble, even some of which become inactive.

'Aisyiyah has indeed become on the same position with other women's organization in Indonesia, it has even been recognized as a fairly big organization of women. Three main fields of activity of 'Aisyiyah consist in preaching, education, and social. The actual effort of 'Aisyiyah in education and social sectors have provided contribution to the efforts authorized by government. 'Aisyiyah is able to 
involve in the establishment of mental and spiritual. By preaching, 'Aisyiyah can lecture its members to live the life in line with the wish of Islam (SutrisnoKutoyo, 1998: 423).

In 2014, 'Aisyiyah reached the age of 100 as the first women's movement organization in the country. 'Aisyiyah becomes a leading organization, for which it has been struggling in the name of the rights of women in accordance with the nature and syariah put in the order of Islam. Such important role was engaged by 'Aisyiyah during the second women congress that ultimately generated the Mother's Day, commemorated nationally and annually on December 22 (Darban, 2010).

\section{DISCUSSION}

Ideally, the existence of 'Aisyiyah is in the similar position of Muhammadiyah, which therefore, a hypothesis is made that branches and subsections of 'Aisyiyah are amounted to 17 Branches and 82 Subsections (2010). A greater possibility of change about such data might be found following to a field examination. This research is a part of roadmap of AIK Study Centre's research lasting to 2017. The mapping conducted to the Muhammadiyah organization in terms of branches and subsections, as well as its autonomous organizations, are meant to collect academically organizational data as it can be taken scientifically into account.

However, the lack of accuracy of data and files from every period of ruling leadership brings about a dilemma that the development of "Aisyiyah in Sukabumi cannot be tracked in a clear modality, precisely the same with the development of Branches and Subsections.

\section{A. Condition of Branches and Subsections of 'Aisyiyah in Sukabumi Regency}

The number of districts in the region of Sukabumi Regency is amounted to 47, divided into 364 villages in three sub-districts. Its centralized government is located in PelabuhanRatu.

Based on the initial data acquired by the writers from 'Aisyiyah Regional Leadership ( $P W A$ ), the amount of branches and subsections of "Aisyiyah located in Sukabumi regency is amounted to five branches and 16 subsections.

According to a field survey conducted in regard of that matter, the data elucidated comparison between the amount of villages/sub-districts and branches as well as subsections of' 'Aisyiyah in Sukabumi Regency is as follow:

Table4.1. Comparsion between the Amount of Sub-districts/Villages and Branches as well as Subsections of 'Aisyiyah in Sukabumi Regency

\begin{tabular}{|c|c|c|c|c|c|}
\hline No & Name of District & Name of Branch & Name of Sub-district/Village & \multicolumn{2}{c|}{ Comaprion of Amount } \\
\cline { 3 - 5 } & & & Village & Subsection \\
\hline 1 & Kadudampit & Cipetir & Sukamaju & 9 & 10 \\
\hline & & LebakSiuh & Sukamaju & & 4 \\
\hline & & CipetirGirang & Sukamaju & 5 & 3 \\
\hline 2 & Sukaraja & Sukaraja & Sukaraja & 14 & 17 \\
\hline \multicolumn{2}{|c|}{ Total }
\end{tabular}

From the above table, it can be obtained that the major amount of sub-districts/villages is higher than that of the Subsections. Although Sukamaju Village has 3 Branches, this is due to the village becomes the basis of Muhammadiyah/'Aisyiyah. Therefore, only Kadudampit District owns the highest number of Subsections compared to the other districts. Meanwhile, for subsections, they mostly have less number than sub-districts/villages.

\section{B. Condition of Branches and Subsections in Sukabumi Regency}

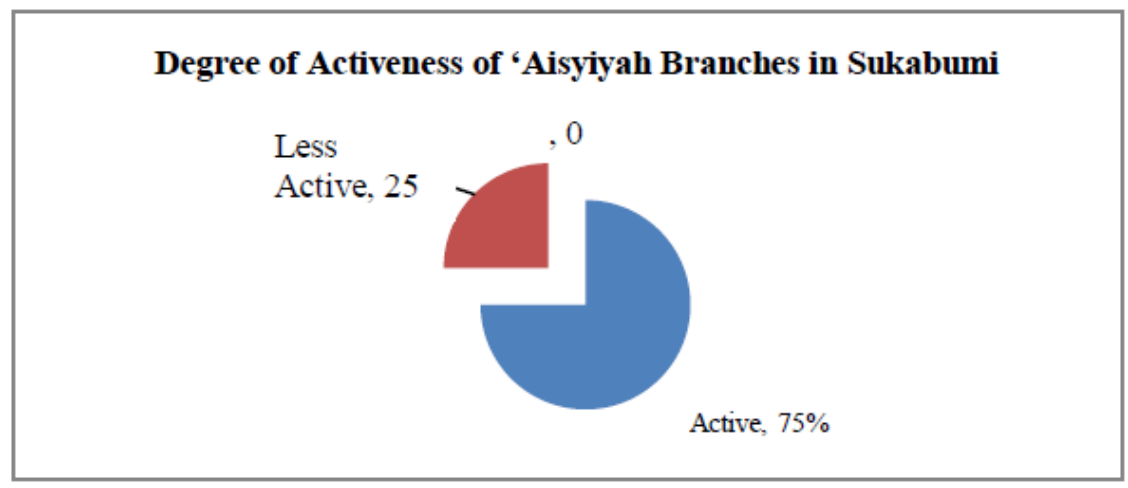

Chart2.1 
From the chart above, it can be inferred that it is the condition of the actual 'Aisyiyah Branches. The amount of active Branches is two, namely Cipetir and Sukaraja (Score of 7-10), and the amount of which are inactive is one, namely LebakSiuh (Score of 4-6).

The writers have firstly described the degree of activeness of Branches in SUkabumi Regency. The writers then would like to elucidate the condition of Branches based on the result of the research. It can be informed that the majority of Branches is located in village area. Thus, the participation of 'Aisyiyah in the last Leaders Conference (Musypim) was represented by the two Branches, namely Cipetir and Sukaraja, in 2010 and 2011. Meanwhile, two other Branches, namely CipetirGirang and LebakSiuh, participated in the 2005's Leaders Conference only. Thus, regarding the status of Branches office, two branches have possessed offices with Freehold title, namely 1 branch joining in the Charitable Enterprise and another branch joining in the 'Aisyiyah manager's house.

Subsequently, it is informed that special religious assembly for the Branches' board of leaders has been frequently implemented, precisely once a month. Most of the Branches have also implemented such religious assembly for people in general.

According to the other data, it can be concluded that some of the Branches have possessed corps of mubalighat, as well as mubalighat course. Thus, only three Branches have mosques as a place for performing worships and other events. None of the branches have Mushala, and only one branch doesn't possess any activity center and independent place of worship.

\section{Condition of Subsections of 'Aisyiyah in Sukabumi Regency}

If the condition of Subsections of 'Aisyiyah is performed by score, so it will be acquired with the following chart:

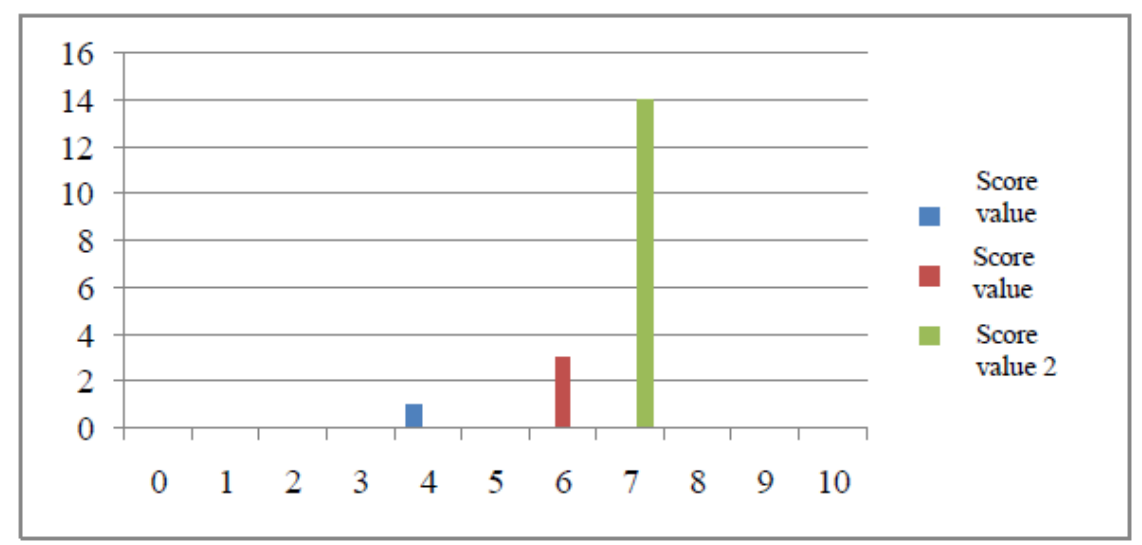

Chart2.1. Amount of Subsections per Score in Sukabumi Regency

Therefore, it can be counted into percentage the degree of activeness of Subsections of 'Aisyiyah in Sukabumi Regency by the following result:

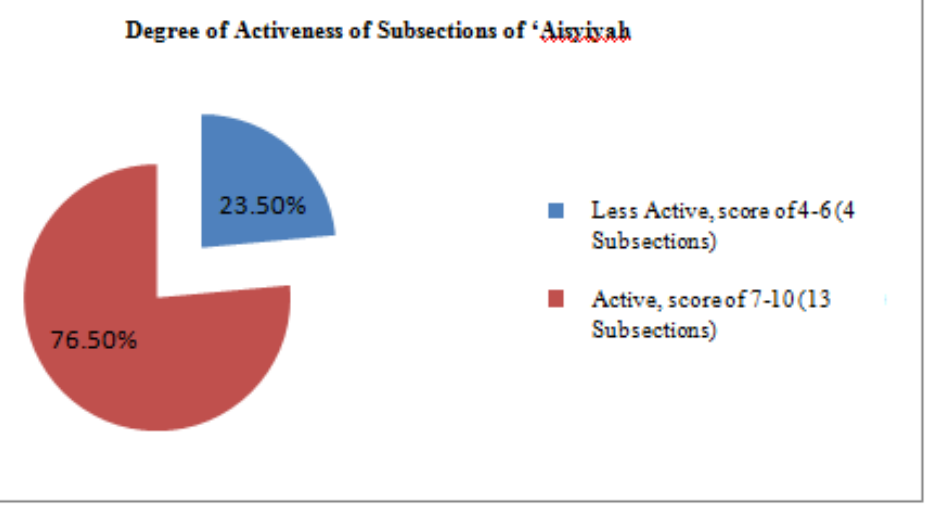

Chart2.2

All of the Subsections of "Aisyiyah are in less active condition since the the amount of the score is ranged in 4-7, respectively, in active condition (76.50\%) and the remaining is less active $(23.50 \%)$. 
In the data above, he writers have also generally mapped the degree of activeness of Subsections of 'Aisyiyah in Sukabumi Regency. The elaboration of such condition will be elucidated below.

It can be obtained that most of the Subsections is located in village area. The last Leaders' Conference (Musypim) participated by 'Aisyiyah's Subsections in Sukabumi regency was represented by 12 Subsections in 2005.

From the data above, it can be inferred that the Subsections' office status from 14 Subsections in Sukabumi Regency only have 14 subsections joining in the manager's house as the office, while 3 other subsections join in the Charitable Enterprises, and none of which have Freehold titles.

All of the 'Aisyiyah's Subsections hold monthly religious assembly more than 2 times. This aspect shows that religious assembly within the subsections of "Aisyiyah is still implemented with the spirit of science and required to be improved in the future. Thus, the majority of the elucidated Subsections have placed mosques as the activity center for their jamaah.

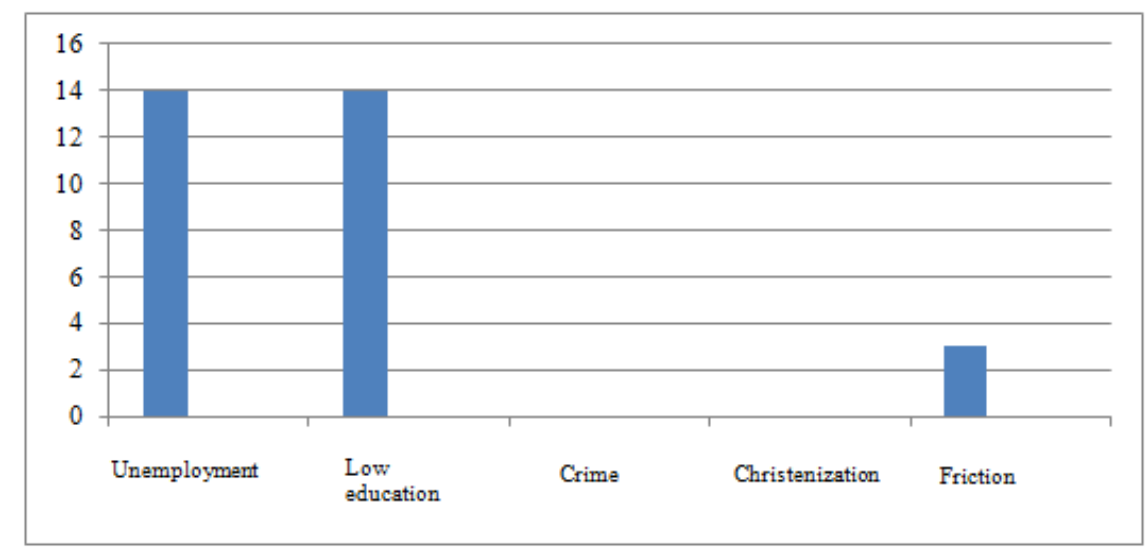

Chart2.2. Problems faced by 'Aisyiyah's Subsections

From the above chart, it is acquired that the problem in the subsections of 'Aisyiyah is that the high level of unemployment, low education. Thus a small amount of the subsections are dealing with frictions with society, such as a difference in performing worship, etc.

Regarding the total amount of 'Aisyiyah members within the subsections, as it has been surveyed, no more than 10-50 people participate in each of the subsections. This aspect indicates the need for further efforts so that the number of members of 'Aisyiyah increase.

\section{Charitable Enterprises of 'Aisyiah in Sukabumi Regency}

The Articles of Association of Muhammadiyah name 14 charitable enterprises that can be realized, in which it can be classified into eight working sectors. One of the charitable enterprises is in education sector. The education pioneered by Muhammadiyah is the education based on two orientations, namely the mixture of public school system and Islamic boarding school. In order to bring the education path into reality, Muhammadiyah has then established charitable enterprises in terms of modern schools that lecture about religion, Islamic boarding schools that teach general/modern sciences, as well as tertiary education or university.

This research, on charitable enterprises of 'Aisyiyah in Sukabumi, shows that a charitable enterprise in terms of education sector is the most owned enterprise, namely in terms of school for kindergarten/Raudhatul Athfal. There are five Kindergarten or Raudhatul Athfaldistributed in five area, respectively, in Sukamaju Village in Kadudampit District (three Kindergarten/RA), in Sukamekar Village in Sukaraja District (one RA), and in Lengkong Village (one Kindergarten).

The following list enlists the name of charitable enterprises of 'Aisyiyah in Sukabumi Regency distributed in the Branches of 'Aisyiyah:

1. Aisyiah 1 Cipetir Girang Kindergarten (RA/TK)

2. Aisyiah 2 Lebak SiuhKindergarten (RA/TK)

3. Aisyiah Busthanul Athfal IIIKindergarten (RA/TK)

4. Aisyiah LengkongKindergarten (RA/TK)

5. Muhammadiyah SukarajaKindergarten (RA/TK) 


\section{CONClusion}

The research can be concluded as follow:

1. The Branches in Sukabumi Regency is amounted to 2 branches, located in 2 districts. This amount is not comparable with the total amount of districts in Sukabumi Regency, which is amounted to 47.

2. The activeness condition of most branches and subsections in Sukabumi Regency is in the level of active.

3. The charitable enterprises conducted by 'Aisyiyah Regional Leadership in Sukabumi has higher number in education sector.

\section{REFERENCES}

ANRI, (2012). Catatan Arsip100 tahun Sukabumi. Jakarta : Arsip Nasional Republik Indonesia.

Darban, Adabi. (2010). 'Aisyiyah - Gerakan Perempunan Pertama di Indonesia. Pusat Studi Perempuan dan Gender UGM. Yogyakarta : Penerbit UGM.

Kutoyo, Sutrisno (1998), Kiai Haji Ahmad Dahlan

Sholeh, Rosyad, Manajemen Dakwah Muhammadiyah, Yogyakarta: Suara Muhammadiyah, 2012.

Siwiyanti, Leonita et al (2013). Peta Kondisi Cabang dan Ranting Muhammadiyah Sukabumi. Pusat Studi Al-Islam dan Kemuhammadiyahan. Sukabumi : PS AIK.

Stephen P. Robbins, Organizational Behavior : Global and Southern African Perspectives, $2^{\text {nd }}$ Edition (Cape Town : Pearson Education South Africa (Pty) Ltd., 2010) p.15.

Tim, (2012). Pedoman Pengembangan Cabang dan Ranting Muhammadiyah. LPCRPP Muhammadiyah. Yogyakarta : LPCR PP Muhammadiyah

Umar, Muthia (2014). Pidato Iftitah Ketua PWA Jawa Barat. Musyawarah Pimpinan Wilayah 'Aisyiyah Jawa Barat . Bandung : PWA Jawa Barat

Umam, Khaerul, Perilaku Organisasi, Bandung:CV. Pustaka Setia, 2010.

------, Majalah Suara Muhammadiyah, No. 14 Bulan Juli 2012.

\section{AUTHORS' BIOGRAPHY}

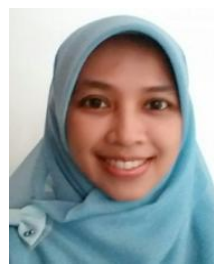

Prahasti Suyaman, lecturer of Law Faculty in Muhammadiyah University of Sukabumi. Interesting in Islamic Law.

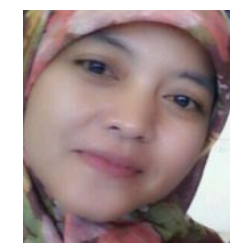

Leonita Siwiyanti, Lecturer in Muhammadiyah University of Sukabumi.

Yuni Sri Wahyuni, lecturer of Sciene and Technology Faculty in Muhammadiyah university of Sukabumi. 